\title{
Analyzing Pakistan's Trade Opportunity with Turkey
}

\section{Asha Gul*}

\begin{abstract}
Growing economic cooperation between the Pakistani and Turkish governments-manifested in the recently proposed preferential trade agreement (PTA)-has served to strengthen the historically good relations between both countries. This paper explores the trade relationship between Pakistan and Turkey in an attempt to analyze the potential gains for Pakistan under the proposed PTA. We evaluate potential trade opportunities using descriptive statistics and three trade indices: a trade complementarity index, export similarity index, and intraindustry index. Our findings suggest that Pakistan's trade surplus with Turkey, strong export similarities, and intra-industry trade would allow greater opportunities for firm synergies between the two countries. This, in turn, would help Pakistan achieve greater value addition and a broader market base for its exports. The Government of Pakistan should, therefore, lobby strongly for the proposed PTA (which might later evolve into a free trade agreement) and leverage the agreement in such a way that Pakistan can maximize its potential benefits.
\end{abstract}

Keywords: Preferential trade agreement, Pakistan, Turkey, trade complementarity index, export similarity index, intraindustry trade index.

JEL classification: F13, F14, F15.

\section{Introduction}

Pakistan and Turkey have long had good relations, which have been strengthened by growing economic cooperation between the two governments in sectors such as energy, transport, communications, infrastructure, textiles, automobiles, agriculture, industry, food processing, dairy development, information technology, oil and gas, and trade ("Erdogan trip," 2013). An important aspect of this thriving relationship is the proposed preferential trade agreement (PTA), which is expected to "help boost trade ties and achieve the mutually agreed trade target of two billion dollars" ("Pakistan calls for early finalization," 2012). This underlies

\footnotetext{
* Teaching and Research Fellow, Center for Research in Economics and Business (CREB), Lahore School of Economics.
} 
the motivation for this study: our objective is to empirically analyze the existing trade relationship between Pakistan and Turkey and explore potential opportunities that Pakistan might exploit under the PTA.

While there is a significant body of literature available on Pakistan's trade prospects with other important trading partners such as China and the SAARC countries (particularly India), only a handful of studies have attempted to explore the potential for trade with Turkey, even though the latter is a larger export market than India ${ }^{1}$ and there is stronger political goodwill between the two. Not only is there little empirical work on Pakistan's trade opportunities with Turkey, but existing studies also have a very narrow focus and do not provide a comprehensive insight into this trade relationship.

Since independence in 1947, Pakistan has maintained friendly relations with Turkey owing to a largely common culture and geopolitical considerations. Both are founding members of the Economic Cooperation Organization (ECO) and part of the Developing 8 (D-8) countries as well as the Organization of Islamic Cooperation. In an attempt to strengthen bilateral commercial and economic relations, Turkey and Pakistan have signed a number of agreements including the Trade Agreement (1965), Economic and Technical Cooperation Agreement (1976), Prevention of Double Taxation Agreement (1988), and Reciprocal Promotion and Protection of Investments Agreement (1997). Within the framework of the 1976 agreement, the countries established the Turkey-Pakistan Joint Economic Committee Mechanism. Since then, regular meetings have been held in Ankara and Islamabad with public institutions from both countries taking part to evaluate bilateral economic and commercial relations.

The Turkey-Pakistan Business Council was founded in order to strengthen relations between the private sectors of the two countries and encourage new business contacts. After a five-year hiatus, the council last met in October 2011. Turkey also initiated the Turkey-AfghanistanPakistan Trilateral Summit meetings in 2007 with the aim of establishing mutual confidence and cooperation among the three countries. The sixth meeting of the summit was held in December 2011 in Istanbul.

The last few years have seen an unprecedented increase in collaboration between the governments of both countries. A high-level

\footnotetext{
${ }^{1}$ As of 2012, Pakistan's exports to Turkey were about US\$ 0.42 billion, comprising around 1.69 percent of Pakistan's total exports. Pakistan's exports to India were US\$ 0.35 billion, comprising around 1.41 percent of the former's total exports.
} 
cooperation council (HLCC) at the prime ministerial level was established in 2009 and is expected to meet annually in both countries to review trade and economic cooperation. At the first HLCC meeting held in Ankara in December 2010, 18 memorandums of understanding (MOUs) and agreements were signed between the two countries. Another nine cooperation agreements relating to investment, energy, and communications were finalized at the second HLCC meeting held in Pakistan in May 2012.

Cooperation between the two partners received an even stronger push in 2013 when the Prime Minister of Pakistan visited Istanbul, followed shortly after by the Turkish Prime Minister's visit to Pakistan in December. Both heads of state agreed to strengthen their bilateral relationship for greater mutual gains: three important MOUs were signed between the Punjab Industrial Department and Turkey Cooperation Agency, Pakistan Railways and the Turkish Logistics Organization, and the Pakistan Standard Quality Control Authority and Turkish Standards Institution. However, the most important product of this increasing cooperation has been the two countries' mutual agreement to conclude talks concerning the PTA.

Following the proposal to establish a PTA in 2011, some studies have analyzed the prospects and opportunities it holds-most conclude that the PTA favors greater gains for Turkey. Broadly, these studies have employed a gravity model to compute the unrealized trade potential by taking the difference between the predicted and actual trade volumes for both countries.

Khan, Haq, and Khan (2013) predict $^{2}$ that Pakistan's actual trade with Turkey is only 55 percent of the predicted trade flow (for 2010), implying that there is a significant opportunity for expanding trade gains through a PTA. Similarly, Suvankulov and Ali (2012) estimate an augmented gravity model for 1996-2009 and emphasize the unrealized potential for trade between Turkey and Pakistan. An interesting finding of this study is that, while actual Turkish exports to Pakistan are significantly lower than the predicted flows, Pakistani exports to Turkey are reasonably higher than predicted, implying that Turkey has a greater opportunity to expand its export market in Pakistan given any PTA between the two countries. The authors also compute a trade complementarity index (TCI) ${ }^{3}$

\footnotetext{
${ }^{2}$ The study estimates a gravity model using panel data for 1990-2010 with a frequency of two years

${ }^{3}$ For 2009, using UN Comtrade data for the two-digit SITC Revision 4 classification of goods and services.
} 
of 0.41 for Turkish exports to Pakistan, while the TCI for Pakistani exports to Turkey is 0.27 , reinforcing Turkey's advantage over Pakistan in the trade relationship (and, therefore, in any subsequent trade agreement).

Kamal, Khan, Ghani, and Muhayudin (2012) estimate a gravity model to determine the trade potential of Pakistan with ECO countries, using a cross-sectional dataset of 153 countries for 2008. Their findings also reveal that Pakistan's trade level with Turkey is far higher than predicted by the gravity model.

This study aims to provide a more comprehensive insight into the prospects and potential for trade between Pakistan and Turkey, especially in view of the proposed PTA. It also aims to determine whether the agreement promises any expected gains for Pakistan. Section 2 sets the context by providing a comparative analysis of Pakistan and Turkey in the world trade market. Section 3 traces the status quo trade relations between the two countries by analyzing some important descriptive statistics over the last decade (2003-12). Section 4 explores potential trade opportunities between the countries using a trade indices analysis. Section 5 concludes the study with recommendations for the way forward.

\section{Pakistan and Turkey's Comparative Status in World Trade}

While Pakistan and Turkey have much in common, their position and performance in the world market is markedly different. Although both countries have maintained a relatively stable GDP level in the last decade, the Turkish economy is almost five times the size of the Pakistan economy with an average GDP of around US\$ 526 billion compared to Pakistan's average GDP of about US\$ 120 billion (Figure 1).

Figure 1: Comparative GDP at constant 2005 US\$

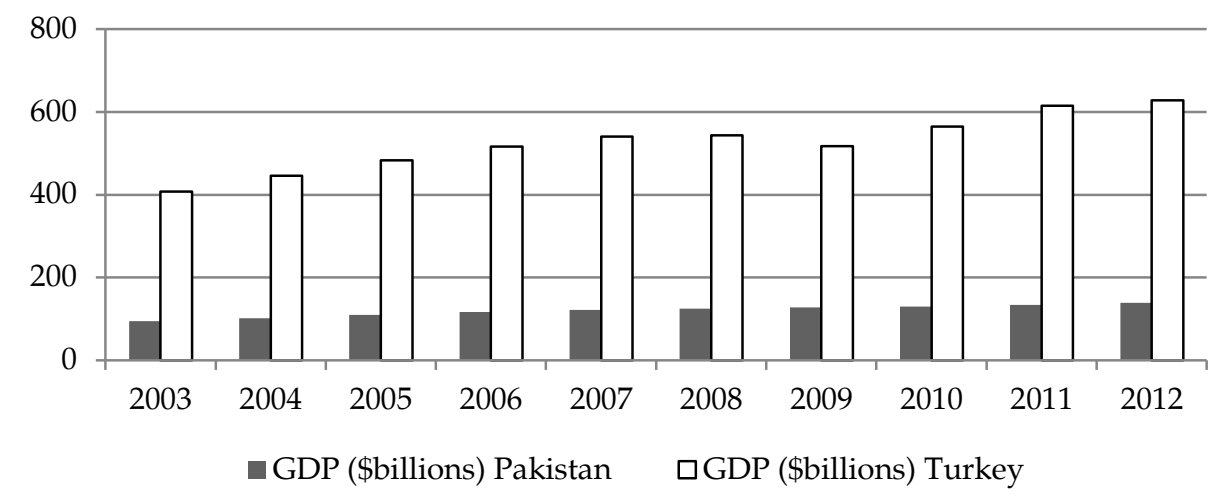

Source: United Nations Statistics Division (2010). 
However, the GDP growth rates reveal strong variations over the last decade, both for Pakistan and Turkey as well between the two countries (Figure 2). Although Turkey has been one of Europe's fastest growing economies, it plummeted sharply in 2009. The economy recovered soon after with a high growth rate during 2010/11. In 2012, the growth rate nosedived once again to 2.2 percent. Pakistan's GDP growth rate has followed a similar pattern, declining from 7.7 percent in 2005 to around 4 percent in 2012. However, the country has managed to avoid sharp fluctuations in the growth rate and has sustained an average positive growth rate of 4.4 percent.

Figure 2: Comparative GDP growth rates, 2003-12

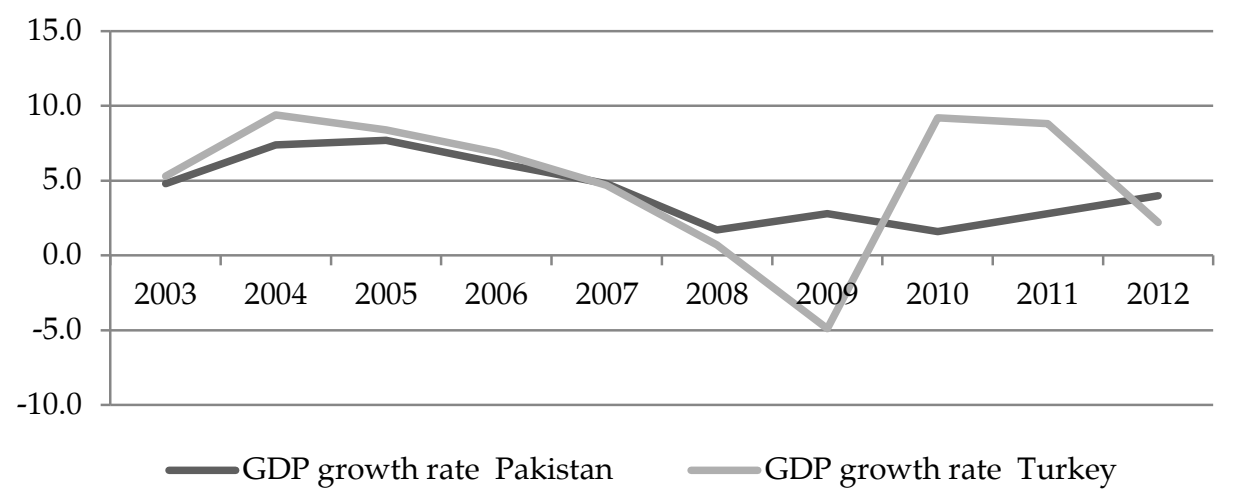

Source: United Nations Statistics Division (2010).

Although it is difficult to determine which factors might best explain the prevailing growth rates in the two countries over the last decade, one important factor has undoubtedly been their level of integration with the world economy. Almost 50 percent of Turkey's GDP is attributable to international trade (Figure 3); the corresponding figure for Pakistan is only 30 percent and this has remained relatively stable over the last decade despite increasing global economic integration. This indicates that Pakistan has lagged behind in capitalizing on the dynamic growth in world markets, which is also a plausible reason for its relatively sluggish performance over the last decade. 
Figure 3: Comparative share of trade in GDP 2003-12

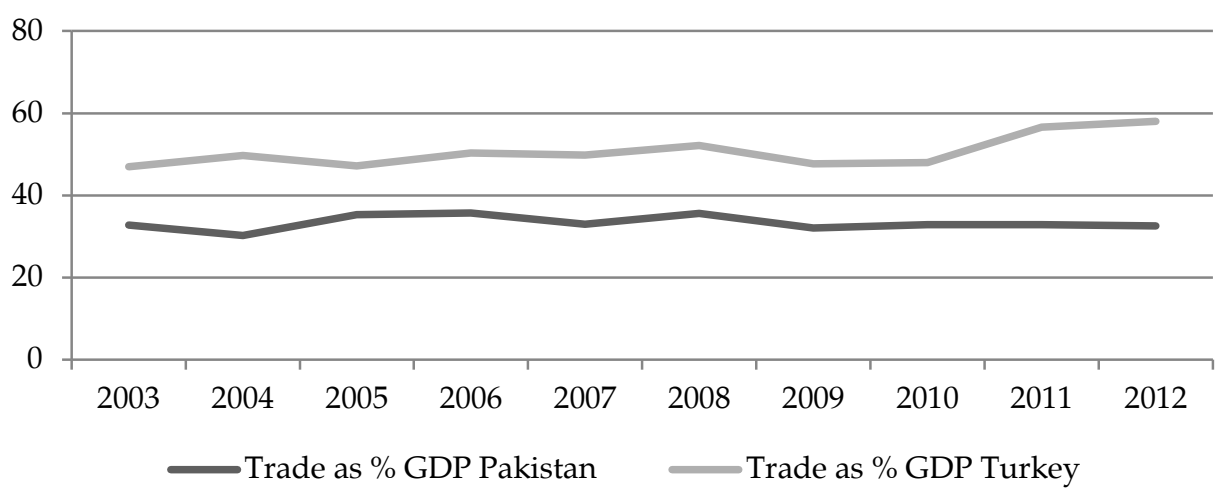

Source: United Nations Statistics Division (2010).

Analyzing the volume of exports and imports for both countries shows that both Pakistan and Turkey are net importers (Figures 4 and 5). Given the difference in the size of the two economies, Turkish imports and exports are almost five times the size of Pakistan's imports and exports. However, an important consideration is that, while Turkey has steadily increased both its exports and imports in the world market, Pakistan's exports have remained relatively stagnant (around US\$ 20 billion) compared to its increasing imports (almost US\$ 44 billion in 2012).

Figure 4: Total exports to the world, 2003-12

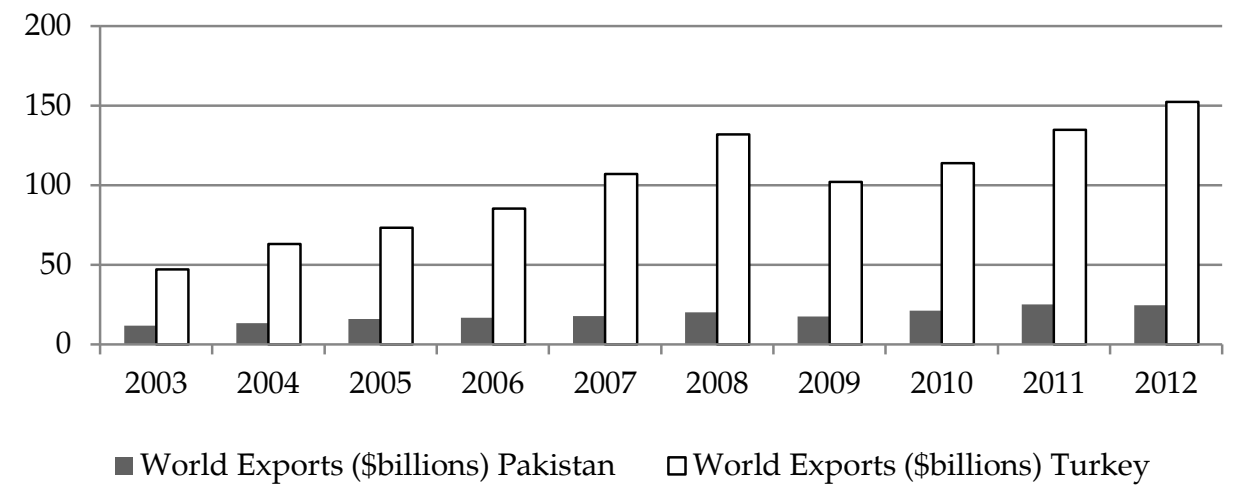

Source: United Nations Statistics Division (2010). 
Figure 5: Total imports from the world, 2003-12

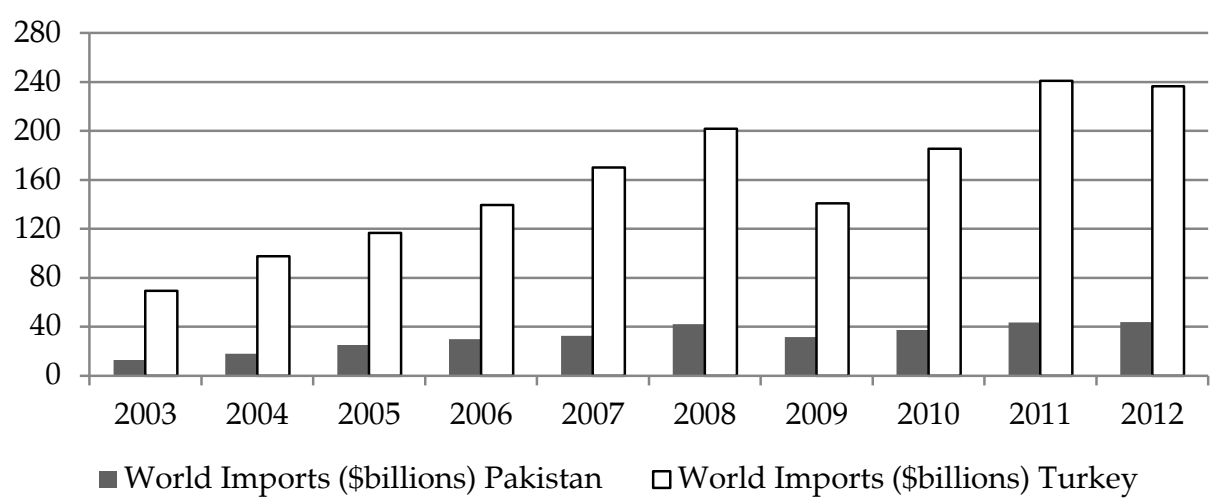

Source: United Nations Statistics Division (2010).

Further analysis of the structure of exports and imports reveals that Turkey has a highly diversified portfolio of exports and imports (Tables 1 and 2) while Pakistan has a strongly concentrated basket of imports and exports. Almost 40 percent ${ }^{4}$ of its exports stem from the textiles sector alone, followed by rice (7.65 percent) and jewelry (6.54 percent). On the other hand, Turkey's leading exports include gold (8.75 percent), petroleum oils (4.45 percent), and cars (3.98 percent).

Table 1: Pakistan's top ten exports in 2012

\begin{tabular}{llrr}
\hline Code & \multicolumn{1}{c}{ Commodity $\boldsymbol{i}$} & \$ billion & \% share \\
\hline Total & All products & 24.61 & 100.00 \\
'6302 & Bed, table, toilet, and kitchen linen & 2.52 & 10.22 \\
'5205 & Cotton yarn (85 percent or more cotton, not & 2.10 & 8.54 \\
& retail) & & \\
'1006 & Rice & 1.88 & 7.65 \\
'7113 Articles of jewelry and parts thereof & 1.61 & 6.54 \\
'5209 & Woven cotton fabric (weight over 200 g/m2) & 1.09 & 4.42 \\
'6203 Men's suits, jackets, trousers, shorts, etc. & 0.92 & 3.74 \\
'5208 & Woven cotton fabric (weight less than 200 g/m2) & 0.73 & 2.96 \\
'4203 & Apparel and accessories of leather or & 0.63 & 2.57 \\
& composition leather & & \\
\hline
\end{tabular}

${ }^{4}$ This includes household linen (10.22 percent), cotton yarn (85 percent or more cotton, not retail; 8.54 percent), woven cotton fabric (weight over $200 \mathrm{~g} / \mathrm{m} 2 ; 4.42$ percent), men's garments (3.74 percent), woven cotton fabric (weight less than $200 \mathrm{~g} / \mathrm{m} 2 ; 2.96$ percent), apparel and accessories of leather or composition leather (2.57 percent), women's garments ( 2.40 percent), and men's shirts (knitted or crocheted, 2.21 percent). 


\begin{tabular}{llrr}
\hline Code & \multicolumn{1}{c}{ Commodity $\boldsymbol{i}$} & \$ billion & \% share \\
\hline '6204 & Women's suits, jackets, dresses, skirts, and shorts & 0.59 & 2.40 \\
'2523 & Cement, portland, aluminous, slag, super- & 0.57 & 2.32 \\
& sulfate, and similar hydraulic & & \\
'6105 & Men's shirts, knitted or crocheted & 0.54 & 2.21 \\
& Total share of top ten exports & & $\mathbf{5 3 . 5 8}$ \\
\hline
\end{tabular}

Source: United Nations Statistics Division (2010).

Not only does Pakistan export a narrow range of products, but also a significant share of its exports comprises low value-added products (for example, a major portion of textile exports). Turkish exports, on the other hand, are high value-added products. Even in the textiles market in which Pakistan seems to have a comparative advantage, Turkey remains a major player and exports a higher volume of high value-added products such as T-shirts and women's suits, jackets, and dresses (readymade garments).

Table 2: Turkey's top ten exports in 2012

\begin{tabular}{llrr}
\hline Code & \multicolumn{1}{c}{ Commodity $\boldsymbol{i}$} & \$ billion & \% share \\
\hline Total & All products & 152.5 & 100.00 \\
'7108 & Gold, unwrought or in semi-manufactured form & 13.34 & 8.75 \\
'2710 & Petroleum oils, not crude & 6.78 & 4.45 \\
'8703 & Cars (incl. station wagons) & 6.07 & 3.98 \\
'7214 & Bars and rods of iron/non-al/s, nfw than forged, hr & 5.40 & 3.54 \\
'8708 & Motor vehicle parts and accessories & 3.40 & 2.23 \\
'8704 & Trucks, motor vehicles for transporting goods & 3.39 & 2.22 \\
'6109 & T-shirts, singlets and vests, knitted or crocheted & 3.09 & 2.03 \\
'7113 & Articles of jewelry and parts thereof & 2.68 & 1.75 \\
'8544 & Insulated wire/cable & 2.38 & 1.56 \\
'6204 & Women's suits, jackets, dresses skirts \& shorts & 2.20 & 1.45 \\
'8528 & Television receivers & 2.17 & 1.42 \\
& Total share of top ten exports & & 33.38 \\
\hline
\end{tabular}

Source: United Nations Statistics Division (2010).

Pakistan's import structure is also heavily concentrated with petroleum and oils comprising almost 40 percent of the total import bill (Table 3). It is one of the reasons for Pakistan's increased trade deficit: the demand for oil has risen with improved growth rates and, when combined with increasing oil prices in the world market, this has led to an almost threefold increase in imports over the last decade. Electrical appliances and 
cars, which are other major import items, are also classified as high valueadded products.

Turkey, on the other hand, has a more diversified imports portfolio: the share of its top ten imports is only about 25 percent (Table 4). While oil is a major import, it constitutes only 6.6 percent of total imports. Other important imports include industrial raw materials such as ferrous waste and scrap, remelting scrap ingots/iron/steel, gold (unwrought or in semimanufactured form), petroleum gases, refined copper and copper alloys (unwrought), and polymers of propylene or other olefins (in primary form).

Table 3: Pakistan's top ten imports in 2012

\begin{tabular}{llrr}
\hline Code & \multicolumn{1}{c}{ Commodity $\boldsymbol{i}$} & \$ billion & \% share \\
\hline Total & All products & 43.81 & 100.00 \\
'2710 & Petroleum oils, not crude & 9.97 & 22.75 \\
'2709 & Crude petroleum oils & 5.27 & 12.03 \\
'1511 & Palm oil and its fraction & 2.13 & 4.87 \\
'8517 & Electric appliances for line telephones & 1.39 & 3.18 \\
'8703 & Cars (incl. station wagons) & 0.90 & 2.06 \\
'7204 & Ferrous waste and scrap, remelting scrap & 0.62 & 1.41 \\
& ingots/iron/steel & & \\
'2902 & Cyclic hydrocarbons & 0.61 & 1.40 \\
'5201 & Cotton, not carded or combed & 0.56 & 1.29 \\
'2701 & Coal (briquettes, ovoids, similar solid fuels) & 0.55 & 1.25 \\
'8908 & Vessels and other floating structures for & 0.53 & 1.20 \\
& breaking up & & \\
'1205 & Rape or colza seeds, whether or not broken & 0.49 & 1.12 \\
& Total share of top ten imports & & $\mathbf{5 2 . 5 5}$ \\
\hline
\end{tabular}

Source: United Nations Statistics Division (2010). 
Table 4: Turkey's top ten imports in 2012

\begin{tabular}{llrc}
\hline Code & \multicolumn{1}{c}{ Commodity $\boldsymbol{i}$} & \$ billion & \% share \\
\hline Total & All products & 236.54 & 100.00 \\
'2710 & Petroleum oils, not crude & 15.62 & 6.60 \\
'7204 & $\begin{array}{l}\text { Ferrous waste and scrap, remelting scrap } \\
\text { ingots/iron/steel }\end{array}$ & 9.42 & 3.98 \\
'7108 & Gold, unwrought or in semi-manufactured form & 7.64 & 3.23 \\
'8703 & Cars (incl. station wagons) & 7.25 & 3.07 \\
'8708 & Motor vehicle parts and accessories & 4.49 & 1.90 \\
'2711 & Petroleum gases & 2.95 & 1.25 \\
'7403 & Refined copper and copper alloys, unwrought & 2.88 & 1.22 \\
'8517 & Electrical appliances for line telephones & 2.83 & 1.20 \\
'3902 & Polymers of propylene or other olefins, in & 2.78 & 1.17 \\
& primary form & & \\
'3004 & Medicament mixtures (not 3002, 3005, 3006), put & 2.74 & 1.16 \\
& in dosage & & \multirow{2}{*}{ 24.78 } \\
\hline
\end{tabular}

Source: United Nations Statistics Division (2010).

Unlike their different export and import structures, Pakistan and Turkey's export markets are relatively similar. In 2012, Pakistan's largest export markets included the US (14.9 percent), ${ }^{5}$ the European Union (EU) (12.02 percent), the UAE (11.67 percent), China (10.64 percent), and Afghanistan (8.53 percent); Turkey ranked as the 8th largest export market. Turkey's largest export market, on the other hand, was the EU (more than 21.43 percent), followed by Iraq (7.10 percent), Iran (6.51 percent), and the UAE (5.36 percent). Pakistan is a very small export market ${ }^{6}$ for Turkey with a share of only 0.18 percent of total exports. On the imports side, Pakistan imports largely from the UAE (16.46 percent), China (15.26 percent), and Saudi Arabia (9.78 percent), while Turkey's largest import market is Russia (11.26 percent), followed by Germany ( 9.05 percent), China (9 percent), and the US (5.97 percent). Turkey is Pakistan's 33rd (as of 2012) most important imports market, accounting for 0.43 percent of total imports to Pakistan. Pakistan is Turkey's 53rd largest import market and constitutes only 0.23 percent of its total imports.

\footnotetext{
${ }^{5}$ Share of exports to the country as a percentage of total exports in 2012, computed using data from the United Nations Statistics Division (2010).

${ }^{6}$ Roughly, Pakistan is Turkey's $60^{\text {th }}$ largest export market in terms of export share and volume.
} 
Broadly, this analysis reveals one very important aspect of the Pakistan-Turkey trading relationship: Turkey holds greater importance for Pakistan both as an export and import market. Given the size of the Turkish economy, even a small percentage gain of the Turkish market would represent a large gain for Pakistan, even if it is trivial from Turkey's perspective.

\section{Trade Between Pakistan and Turkey: The Status Quo}

Turkey has emerged as one of Pakistan's most important trading partners over the last decade with the volume of trade ${ }^{7}$ rising from almost US\$ 0.27 billion in 2003 to near US\$1 billion in 2011 (Figure 6). This impressive increase in trade volume accounts for the proposed PTA with both countries agreeing to strengthen trade relations by expanding the trade volume to almost US\$ 2 billion ("Pakistan calls for early finalization," 2012). However, a cause for concern has been the sharp dip in the volume of trade to almost US $\$ 0.69$ billion in 2012. This raises important questions about the expected gains from the proposed PTA.

\section{Figure 6: Trade volume between Pakistan and Turkey (US\$ billion)}

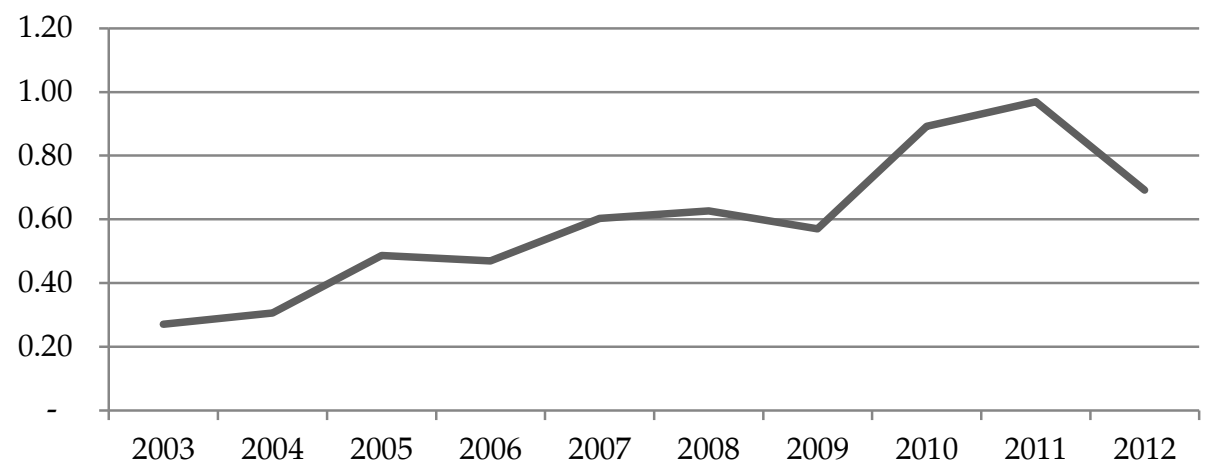

Source: United Nations Statistics Division (2010).

While there is little official evidence to explain this decline in trade volume between the two countries, despite increasing cooperation and political goodwill over the last decade, analyzing the level of exports reveals that the decline is attributable to the sharp fall in Pakistani exports to Turkey (Figure 7). This may have been related to the overall decline in Pakistan's exports in 2012, which should hopefully have been restored by

\footnotetext{
${ }^{7}$ Measured as the sum of Pakistan's exports to Turkey and Turkey's exports to Pakistan.
} 
2013. However, the situation necessitates a decision concerning the proposed PTA sooner than later.

Figure 7: Exports between Pakistan and Turkey, 2003-12

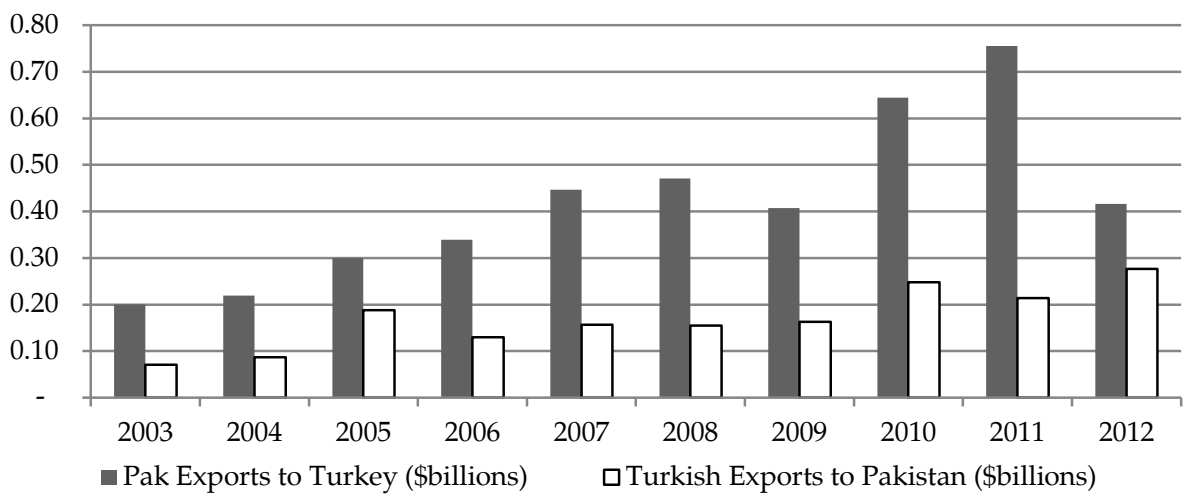

Source: United Nations Statistics Division (2010).

On a more positive note, Pakistan has enjoyed a trade surplus with Turkey over the last decade, which has expanded over the years (Figure 7). In 2003, Pakistan's trade surplus was almost US\$ 0.13 billion; it grew to almost US\$ 0.54 billion in 2011, registering an impressive fourfold increase. Despite the fall in Pakistan's exports to Turkey in 2012, Pakistan has been able to sustain its favorable trade surplus. Given the country's persistent trade deficit, its trade surplus with Turkey is an anchor for Pakistan's external sector.

Another important feature of this trade relationship is that the expanding trade surplus in favor of Pakistan is largely a result of increased exports to Turkey from Pakistan (except in 2012) while imports from Turkey have remained relatively stable. This highlights an important opportunity for Pakistan, which, given its growing ties with Turkey, could prove lucrative. In the context of the proposed PTA, this trend in trade surplus is the first evidence of a positive gain for Pakistan since the PTA will likely enable Pakistan to expand its exports.

However, an important aspect to consider is how imports from Turkey may change under the PTA. If the present trade pattern is expected to continue under the agreement, then Pakistan stands to gain reasonably well. The PTA may also help expand access to the European market ${ }^{8}$ and

\footnotetext{
${ }^{8}$ The EU is a major market for both Pakistan and Turkey, and Turkey is in the process of negotiation a free trade agreement with the EU.
} 
Central Asian Republics via Turkey, which would provide impetus to Pakistan's overall exports.

Almost 80 percent (as of 2012) of Pakistan's exports to Turkey are concentrated in just ten product categories (Table 5) with almost 45 percent of its exports concentrated in textiles. Turkey is the country's fourth largest textile exports market, reinforcing its importance as a trade partner for Pakistan. Other important exports of Pakistan to Turkey include industrial chemicals, carpets, and leather articles.

Interestingly, the structure of Pakistan's exports to Turkey is consistent with the former's overall structure of exports: both are concentrated in relatively few items with the textiles sector accounting for the dominant share of export revenues. This highlights another strong opportunity for Pakistan since Turkey's export market closely matches the former's comparative advantage. If the PTA comes into effect, then Pakistan's strongest export sector is likely to experience significant benefits through market expansion. However, the challenge for Pakistan under this agreement would be to diversify and expand other exports to the Turkish market while sustaining a significant increase in existing export specialties such as textile products. 
Table 5: Pakistan's top ten exports to Turkey in 2012

\begin{tabular}{|c|c|c|c|}
\hline Code & Commodity & \$ billion & \% share \\
\hline Total & All products & 0.42 & 100.00 \\
\hline '3907 & $\begin{array}{l}\text { Polyacetals, other polyethers, epoxide resins, } \\
\text { polycarbonates in primary form }\end{array}$ & 0.08 & 19.95 \\
\hline '5209 & $\begin{array}{l}\text { Woven cotton fabric ( } 85 \text { percent or more cotton, } \\
\text { weight }>200 \mathrm{~g} / \mathrm{m} 2 \text { ) }\end{array}$ & 0.08 & 19.60 \\
\hline '5208 & $\begin{array}{l}\text { Woven cotton fabric ( } 85 \text { percent or more cotton, } \\
\text { weight }<200 \mathrm{~g} / \mathrm{m} 2 \text { ) }\end{array}$ & 0.04 & 9.52 \\
\hline '5205 & $\begin{array}{l}\text { Cotton yarn (not sewing thread, } 85 \text { percent or } \\
\text { more cotton, not retail) }\end{array}$ & 0.03 & 6.11 \\
\hline '2207 & Ethyl alcohol and other spirits & 0.02 & 4.32 \\
\hline '5211 & $\begin{array}{l}\text { Woven cotton fabric (less than } 85 \text { percent, mixed } \\
\text { with manmade fibre, weight }>200 \text { ) }\end{array}$ & 0.02 & 3.98 \\
\hline '3903 & Polymers of styrene, in primary form & 0.02 & 3.64 \\
\hline '5701 & Carpets and other textile floor coverings, knotted & 0.01 & 2.63 \\
\hline '6203 & Men's suits, jackets, trousers, and shorts, etc. & 0.01 & 2.50 \\
\hline '5210 & $\begin{array}{l}\text { Woven cotton fabric (less than } 85 \text { percent cotton, } \\
\text { mixed with manmade fiber) }\end{array}$ & 0.01 & 2.46 \\
\hline '4107 & $\begin{array}{l}\text { Leather of other animals, } \mathrm{o} / \mathrm{t} \text { leather of hd no. } \\
41.08 / 41.09\end{array}$ & 0.01 & 2.03 \\
\hline \multirow[t]{2}{*}{ '4203 } & $\begin{array}{l}\text { Apparel and accessories of leather/composition } \\
\text { leather }\end{array}$ & 0.01 & 2.01 \\
\hline & Total share of top ten exports & & 78.75 \\
\hline
\end{tabular}

Source: United Nations Commodity Statistics Division (2010).

Consistent with Turkey's diversified total exports portfolio, its exports to Pakistan also encompass a greater variety of high value-added items with electrical appliances for line telephones being the most significant export (12.52 percent of Turkey's total exports to Pakistan) (Table 6). Other important exports include aircraft parts, carpets, and petroleum oils. Under the PTA, the carpet industry would stand to gain considerably, given that carpets are major export items for both Pakistan and Turkey. 
Table 6: Turkey's top ten exports to Pakistan in 2012

\begin{tabular}{|c|c|c|c|}
\hline Code & Commodity & $\$$ billion & \% share \\
\hline Total & All products & 0.276 & 100.00 \\
\hline '8517 & $\begin{array}{l}\text { Electrical appliances for line telephones, } \\
\text { including current line systems }\end{array}$ & 0.035 & 12.52 \\
\hline '8803 & Aircraft parts & 0.011 & 3.81 \\
\hline '5702 & $\begin{array}{l}\text { Carpets and floor coverings, woven not } \\
\text { tufted/flocked }\end{array}$ & 0.008 & 2.98 \\
\hline '2710 & Petroleum oils, not crude & 0.007 & 2.62 \\
\hline '3202 & $\begin{array}{l}\text { Synthetic organic or inorganic tanning } \\
\text { substances, tanning preparations }\end{array}$ & 0.007 & 2.38 \\
\hline '2706 & $\begin{array}{l}\text { Tar distilled from coal, lignite, or peat and } \\
\text { other mineral tars, etc. }\end{array}$ & 0.006 & 2.09 \\
\hline '8705 & $\begin{array}{l}\text { Special-purpose motor vehicles (firefighting } \\
\text { vehicles, crane lorries) }\end{array}$ & 0.005 & 1.97 \\
\hline '8483 & $\begin{array}{l}\text { Transmission shafts and cranks, bearing } \\
\text { housing, gearing, etc. }\end{array}$ & 0.005 & 1.84 \\
\hline '8544 & Insulated wires/cables & 0.005 & 1.78 \\
\hline '8409 & $\begin{array}{l}\text { Parts for use solely/principally with motor } \\
\text { engines }\end{array}$ & 0.005 & 1.77 \\
\hline '1512 & $\begin{array}{l}\text { Safflower, sunflower/cotton-seed oil and } \\
\text { fractions }\end{array}$ & 0.005 & 1.68 \\
\hline \multirow[t]{2}{*}{ '4011 } & New pneumatic tires, of rubber & 0.005 & 1.66 \\
\hline & Total share of top ten exports & & 37.10 \\
\hline
\end{tabular}

Source: United Nations Statistics Division (2010).

\section{Trade Indices Analysis: Potential Opportunities}

The literature emphasizes the use of several trade indices, which can provide useful insights into different aspects of a trade relationship. In order to obtain a better picture of the trade opportunities arising from the proposed PTA between Pakistan and Turkey, this section constructs three indices: a Trade Complementarity Index (TCI), Intra-Industry Trade Index (IIT), and Export Similarity Index (ESI). ${ }^{9}$

\footnotetext{
9 Although the literature refers to many trade indices, we have computed and analyzed those recommended by the World Bank in its analysis of trade and export competitiveness (http://web.worldbank.org).
} 


\subsection{Trade Complementarity Index}

One of the most commonly used measures of the degree of trade compatibility between trading partners is the TCI, which is computed as:

$$
T C I=100-\sum_{i=1}^{n} \frac{1}{2}\left|m_{i k}-x_{i j}\right|
$$

where is the percentage share of good $i$ in the global exports of country $j$ and $m_{i k}$ is the percentage share of good $i$ in the global imports of country $k$. The index is 0 when no goods exported by country $j$ are imported by country $k$, and is 100 when the two countries' export and import shares match. Generally, the higher the TCI, the greater is the potential for intraregional trade between the countries in question on the assumption that the exports of country $j$ (supply) match the imports (demand) of country $k$. However, an important limitation of the TCI (see Mamoon, Paracha, Mughal, \& Ayesha, 2011) is that it has an inherent size bias, implying that countries with limited export portfolios (such as Pakistan) are likely to have a lower TCI. This is because the greater the variety of items a country exports, the higher is the likelihood of better matching the import demand of its trading partner.

The TCI for Turkish exports and Pakistani imports is calculated to be 26.89 while the TCI for Pakistani exports and Turkish imports is computed to be 13.16. ${ }^{10}$ Clearly, the TCI favors Turkey twice as much, indicating that it has greater potential for supplying those commodities (exports) that Pakistan demands (imports). This is as expected, given the diversified exports portfolio of Turkey versus the narrowly concentrated exports basket of Pakistan.

This pattern is consistent with Suvankulov and Ali (2012), who estimate a TCI of 41 for Turkish exports to Pakistan and a TCI of 27 for Pakistani exports to Turkey. ${ }^{11}$ One reason for the difference in magnitude of the TCIs could be the difference in product classification: we have computed the TCI using the four-digit commodities classification while Suvankulov and Ali use the relatively more aggregated two-digit commodities classification. Generally, the greater the level of product disaggregation considered, the lower the index is likely to be. However, an important implication of this TCI is that Turkey is in a better position to

\footnotetext{
${ }^{10}$ Using data on the HS four-digit commodities classification for 2012 from the United Nations Statistics Division.

${ }^{11}$ Using data on the two-digit SITC Revision 4 classification of goods and services for 2009 from the United Nations Statistics Division.
} 
serve the Pakistani market and gain from (preferential) trade. This does not, however, necessarily imply that Pakistan stands to lose.

Analyzing Pakistan's trade complementarities with the SAARC region, Mamoon et al. (2011) compute the average TCIs for Pakistan's exports to Bangladesh, India, Sri Lanka, and the SAARC region as a whole $(39,20,33 \text {, and } 24 \text {, respectively })^{12}$ for the period 2007-09. The average TCIs for exports from Bangladesh, India, Sri Lanka, and SAARC to Pakistan stand at $8,58,17$, and 53 , respectively.

Pasha and Imran (2012) also compute the TCI for trade between Pakistan and India using the four-digit HC level commodities classification for 2011; they find that the TCI for Indian exports to Pakistan is almost 42 while that for Pakistani exports to India is only 8.2. Compared with the TCI we have computed for trade between Turkey and Pakistan, there seem to be greater gains for Pakistan under the proposed PTA relative to trade between India and Pakistan since the difference between the TCIs is magnified in the Indian context. Given its existing exports portfolio, Pakistan is better suited to serving the Turkish market than the Indian market ${ }^{13}$ because Pakistan and Turkey have relatively stable and favorable political relations compared to the volatile and uncertain relationship between Pakistan and India.

Another aspect worth highlighting is that the TCI must be analyzed relative to market size. Given that the Turkish market is almost five times that of Pakistan, the latter stands to gain even with a low TCI of 13 since even 13 percent of the Turkish imports market is a potential market worth almost US\$ 26 billion. ${ }^{14}$ Turkey, despite its high TCI, has a potential market in Pakistan of only US\$ 10.8 billion. ${ }^{15}$ Thus, despite its low TCI and narrowly concentrated exports portfolio, Pakistan has the potential to reap benefits from the Turkish market and these expected gains might grow further if Pakistan expands its range of exports to Turkey.

\subsection{Intra-Industry Trade Index}

In recent decades, there has been increasing emphasis on the importance of international trade not only for the benefits associated with greater inter-industry trade but also with greater intra-industry trade (IIT),

\footnotetext{
${ }^{12}$ Computed using the HS two-digit commodities classification.

${ }^{13}$ A TCI of 13 with Turkey versus a TCI of 8 with India.

1413 percent of US\$ 200 billion (Turkish world imports in 2012).

1527 percent of US\$ 40 billion (Pakistani world imports in 2012).
} 
i.e., trade in similar but differentiated products. According to the theoretical literature, differences in the level of technology and human capital can lead to IIT even in products with identical factor input requirements. Another reason for the increase in importance of IIT is the recent growth of regional integration schemes involving cross-country production-sharing arrangements. Therefore, an important dimension of the growing trade relationship between Pakistan and Turkey is the level of existing and potential IIT, using the IIT index.

The IIT index is calculated as follows:

$$
I I T_{i j k}=1-\frac{\left|X_{i j k}-M_{i j k}\right|}{\left(X_{i j k}+M_{i j k}\right)}
$$

where $X_{i j k}$ and $M_{i j k}$ represent the export and import of products from industry $i$ in country $j$ to and from country $k$. The IIT index ranges between 0 and 1 , with larger values indicating greater trade between firms in the same industry. Higher IIT ratios suggest that the net gains from specialization in different products are being exploited and that the participating country is increasing its integration with the world economy.

Computed using the two-digit HS product classification, the IIT index for Pakistan and Turkey in 2012 was around 18.8 percent, with the most important industries being sugar and confectionery, optical/photo/technical/medical apparatus, salt/sulfur/lime and cement, carpets and other textile floor coverings, and manmade filaments.

To put this estimate in perspective, it is important to analyze the IIT index between Pakistan and Turkey with respect to the IIT index with other trading partners. Zaheer, Nizami, and Niazi (2013) find that, on average, Pakistan's IIT index with its major trading partners has increased over the last three decades, with an average IIT ${ }^{16}$ index of 26.28 percent with China, 34.14 percent with India, 19.72 percent with Iran, 25.66 percent with Japan, 17.2 percent with Kuwait, 19.69 percent with Saudi Arabia, 39.52 percent with Singapore, 27.73 percent with the UAE, and 18.01 percent with the US. Comparatively, Pakistan's level of IIT with Turkey is not very high but neither is it very low, being almost similar to that with Iran, Kuwait, Saudi Arabia, and the US. Importantly, given the existing level and pattern of IIT even in similar industries, Pakistan exports low

\footnotetext{
${ }^{16}$ Computed using the one-digit SITC product classification based on data from the United Nations Statistics Division.
} 
value-added products and imports high value-added products on average in the same industry.

More technically, Pakistan has a relatively low level of horizontal IIT and relatively high level of vertical IIT (and a higher level of lowquality vertical IIT versus high-quality vertical IIT). In an analysis of Pakistan-SAARC IIT, Akram (2013) finds that the share of low-quality vertical IIT in total IIT is 69.95 percent and that of high-quality vertical IIT is 12.55 percent; the share of horizontal IIT is 17.50 percent. Although we have not computed the disaggregated IIT between Pakistan and Turkey, their export and import patterns suggest a greater share of (low) vertical IIT. In light of the proposed PTA, it is important to analyze whether there is an opportunity for expanding the existing level of IIT.

\subsection{Export Similarity Index}

A useful measure that provides an insight into the potential for greater IIT and firm synergies is the export similarity index (XSI). This computes the extent to which two countries export similar products:

$$
X S_{j k}=\sum\left[\min \left(x_{i j}, x_{i k}\right)\right]
$$

where $x_{i j}$ is industry $i$ 's export share in country $j$ and $x_{i k}$ is industry $i$ 's export share in country $k$. The index ranges between 0 and 1 , with 0 indicating complete dissimilarity and 1 representing identical export composition. Just like the complementarity index, this index is also subject to aggregation bias which implies that the more disaggregated the data considered, the lower is likely to be the value of the index, and thus there is a certain degree of arbitrariness due to product/industry choice.

Computed using the two-digit HS product classification code, Pakistan and Turkey shared an XSI of about 0.39 in 2012, implying that almost 40 percent of their export industries are similar. A quick review of their major exports (Tables 1 and 2) reveals that textile products are an important market in which both countries are key players. Another interesting finding is that their major export markets tend to overlap (including the US, UK, Saudi Arabia, China, Germany, Italy, Spain, and the Netherlands).

This has two direct (if opposing) implications. First, such a degree of similarity implies that Pakistan and Turkey are competitors for the same markets (a negative effect, since both are striving to gain a larger share of 
the same market). Second, there is considerable opportunity for synergies and horizontal and/or vertical integration and joint ventures between export firms in similar industries (a positive effect, since both countries could, together, capture a larger market and enjoy greater gains). The net effect will depend on the magnitude of these two opposing effects.

Given that Pakistan is a small player with exports worth only about US\$ 24.6 billion compared to Turkey, whose total exports are almost US\$ 152.5 billion, the competition effect of export similarity strongly favors Turkey, especially in terms of the volume of trade. Moreover, while both countries have similar exports, they are players in different segments of the same market: Turkey focuses on the high end of the market spectrum with Pakistan located at the other extreme. Hussain et al. (2013) find that, in 2011, readymade garments constituted about 13 percent of Pakistan's textile exports (worth US\$ 9.6 billion) whereas raw cotton, cotton yarn, and cotton cloth constituted roughly 35 percent. Pakistan's share of the world's top garment products 17 is significantly lower than that of Turkey; Pakistan leads over Turkey in only one market, that for household linen.

This evidence indicates that the competition effect of export similarity is not likely to be very strong. However, it also suggests that therein lies an opportunity for Pakistan to engage in joint ventures and/or production-sharing agreements with Turkey in order to move into higher value-added segments of the same markets in which both operate. This opportunity for firm synergies could be vital for Pakistan, which has been struggling to move up the value chain to augment its export revenues.

Pakistan would also stand to gain greater market access via Turkish firms since Turkey is a major exporter to Europe as well as the Central Asian Republics. Teaming up with Turkey to penetrate these markets-the textiles market in particular, where both countries are important playerswould enable greater gains for both. The magnitude of this gain will certainly be higher for Turkey, given its existing share of world trade, but the percentage gain for Pakistan will be greater and more important.

\footnotetext{
17 Top garments exports within the four-digit classification include: women's suits, ensembles, jackets, blazers, dresses, skirts, divided skirts, trousers, bib- and brace-overalls, breeches, shorts (other than swimwear), jerseys, pullovers, cardigans, waistcoats, and similar articles, knitted or crocheted; men's suits, ensembles, jackets, blazers, trousers, bib- and brace-overalls, breeches, and shorts (other than swimwear); T-shirts, singlets, and other vests, knitted or crocheted; bed linen, table linen, toilet linen, and kitchen linen; pantyhose, tights, stockings, socks, and other hosiery, including stockings for varicose veins and footwear without applied soles, knitted or crocheted; and women's overcoats, car-coats, capes, cloaks, and anoraks (including ski jackets).
} 


\section{Conclusion: The Way Forward}

Pakistan and Turkey undoubtedly have a strategically important and economically lucrative relationship. While Turkey could become a bridge between Asia and Europe, Pakistan shares borders with two large, densely populated economies and could become a gateway to energy-rich Central Asia. However, given their present trade structures and volumes, Pakistan needs Turkey more than the other way around. The present government should, therefore, push harder to have the PTA implemented, given its delay since 2011. Pakistan's trade expansion with Turkey promises substantial gains. Direct gains are an expected outcome, given the present trade surplus and Turkey's large, as yet untapped market. There are also strong indirect gains, given the opportunity for greater firm synergies, enabling long-term structural improvements that are imperative for sustained economic growth in Pakistan.

The most important aspect of this relationship is the strong political will needed to facilitate the strengthening of economic and trade relations between the two countries. As export market shares, India and Turkey are almost equally important, but the key factor that tilts the scales in favor of Turkey is the greater certainty and stability that characterizes its relations with Pakistan. Pakistan must leverage opportunities such as the proposed PTA with Turkey so as to maximize its potential gains. It is high time that the reserves of mutual goodwill between the two countries are channeled into lucrative gains for Pakistan. 


\section{References}

Akram, A. (2013). Pak-SAARC intra-industry trade (Working Paper No. 2013:93). Islamabad: Pakistan Institute of Development Economics.

Erdogan trip: Pakistan, Turkey eye investment bonanza. (2013, December 24). The Express Tribune. Retrieved from http://tribune.com.pk/story/649798/erdogan-trip-pakistanturkey-eye-investment-bonanza/

Hussain, S. T., Malik, K. Z., Khan, U., Faheem, A., Nabi, I., \& Hamid, N. (2013). A comparative analysis of the garments sector of Pakistan (Mimeo). Lahore: International Growth Centre (Pakistan).

Kamal, Y., Khan, M. M., Ghani, U., \& Muhayudin, A. (2012). Pakistan's trade potential in 'ECO' countries: Prospects and challenges. Asian Journal of Business and Management Sciences, 1(7), 60-67.

Khan, S., Haq, I., \& Khan, D. (2013). An empirical analysis of Pakistan's bilateral trade: A gravity model approach. The Romanian Economic Journal, 16(48), 103-120.

Mamoon, D., Paracha, S., Mughal, H., \& Ayesha, A. (2011). Pakistan's trade competitiveness and complementarities in South Asia (Working paper). Islamabad: Pakistan Institute of Trade and Development.

Pakistan calls for early finalization of Pak-Turkey Preferential Trade Agreement. (2012, December 12). Pakistan Today. Retrieved from http:/ /www.pakistantoday.com.pk/2012/12/12/national/pakistancalls-for-early-finalization-of-pak-turkey-preferential-trade-agreement/

Pasha, H. A., \& Imran, M. (2012). The prospects for Indo-Pakistan trade [Special edition]. Lahore Journal of Economics, 17, 293-313.

Suvankulov, F., \& Ali. W. (2012). Recent trends and prospects of bilateral trade between Pakistan and Turkey: A gravity model approach. Journal of International and Global Economic Studies, 5(1), 57-72.

United Nations Statistics Division. (2010). UN comtrade [Database]. Retrieved January-April 2014 from http:/ / comtrade.un.org/

Zaheer, R., Nizami, U., \& Niazi, F. K. (2013). 31 years intra-industry trade of Pakistan. European Journal of Business and Management, 5(31), 173-186. 